\title{
PERBEDAAN PENGETAHUAN WANITA PUS TENTANG METODE KONTRASEPSI MOW SEBELUM DAN SESUDAH PENYULUHAN (Di RT 02 RW 02 Desa Banyakan Kecamatan Banyakan Kabupaten Kediri )
}

Erma Herdyana ${ }^{1}$, Indah Fitri Sulis ${ }^{2}$

Akademi Kebidanan Dharma Husada Kediri Jawa Timur

\begin{abstract}
ABSTRAK
Kontrasepsi merupakan upaya untuk mencegah kehamilan. Salah satu upaya yang dilakukan dalam suatu keluarga yaitu menggunakan cara permanen. Rendahnya pemakaian metode kontrasepsi MOW dikarenakan kurangnya pengetahuan tentang kelebihan dan kelemahan, efektivitas dan efisiensi. Tujuan dari penelitian ini adalah Untuk mengetahui perbedaan pengetahuan wanita PUS tentang metode kontrasepsi MOW sebelum dan sesudah penyuluhan.

Desain penelitian yang digunakan penelitian ini adalah Pra-eksperimental Desain yaitu One Group Pre-Test and Post-Test. Populasi sebanyak 33 wanita PUS dan pengambilan sampel menggunakan total sampel yaitu seluruh populasi menjadi responden. Variabel independen penelitian ini yaitu penyuluhan tentang metode kontrasepsi MOW dan Variabel dependen penelitian ini adalah pengetahuan wanita PUS tentang metode kontrasepsi MOW sebelum dan sesudah penyuluhan. Pengumpulan data pada tanggal 26 Mei 2016, data diperoleh dari kuesioner. Pengolahan data dengan editing, coding, scoring dan tabulating. Analisis data menggunakan rumus Wilcoxon Match Pair Test

Hasil penelitian yang didapatkan dari 33 responden, pengetahuan wanita PUS sebelum diberi penyuluhan 25 responden $(75,76 \%)$ mempunyai pengetahuan cukup. Sedangkan pengetahuan wanita PUS sesudah diberi penyuluhan 28 responden $(84,84 \%)$ mempunyai pengetahuan baik. Berdasarkan hasil uji Wilcoxon Match Pair Test menunjukkan hasil Z sebesar -5.533 dengan tingkat signifikasi $(\sigma)$ sebesar $0.000(\sigma \leq 0,05) \mathrm{H} 1$ diterima.

Berdasarkan hasil penelitian dapat disimpulkan ada perbedaan pengetahuan wanita PUS sebelum dan sesudah penyuluhan. Dengan dilakukan penyuluhan, diharapkan wanita PUS mengamplikasikan pengetahuan dengan baik. Untuk itu diharapkan tenaga kesehatan lebih aktif dalam penyuluhan kontrasepsi MOW untuk meningkatkan pengetahuan tentang kontrasepsi MOW.
\end{abstract}

Kata Kunci : Pengetahuan, Metode Kontrasepsi MOW,

Korespondensi : Perum. Mojototo Indah Blok Y/8 Kota Kediri Hp. 081335431919 Email: herdyanaerma@gmail.com 


\section{PENDAHULUAN}

Program keluarga berencana merupakan suatuprogram yang diselenggarakan dalam rangka pengaturan kelahiran anak, jarak dan usia ideal melahirkan, pengaturan kehamilan, melalui promosi, perlindungan dan bantuan sesuai dengan hak reproduksi untuk mewujudkan keluarga yang berkualitas. Pengaturan kehamilan dalam konteks ini adalah upaya untuk membantu pasangan suami-isteri untuk melahirkan pada usia yang ideal, memiliki jumlah anak, dan mengatur jarak kelahiran anak yang ideal dengan mengggunakan cara, alat dan obat kontrasepsi (BKKBN, 2015).।

Rendahnya pemakaian metode kontrasepsi MOW (Metode Operasi Wanita)dikarenakan kurangnya pengetahuan tentang kelebihan dan kelemahan, efektivitas dan efisiensi serta kesadaran Pasangan usia subur untuk menggunakan metode kontrasepsi ini, dan lemahnya ekonomi juga mempengaruhi partisipasi masyarakat terhadap pemakaian metode kontrasepsi MOW. Meningkatnya cakupan wanita subur 15-49 tahun yang melakukan KB sejalan dengan menurunnya angka fertilitas Nasional. Presentasi penggunaan Kontrasepsi /Cotraktif Prevalen Rate (CPR ) telah melampaui target $(60,1 \%)$ dengan tercapainya $61,9 \%$, namun total fertility rate (TFR) belum mencapai target $(2,36)$ dengan angka tahun 2012 sebesar 2,6 (BKKBN, 2014).

Pencapaian peserta KB baru tahun 2015 masing-masing kontrasepsi bulan Februari 2015 sebanyak 533.067 peserta. Mayoritas peserta KB baru bulan Februari 2015, didominasi oleh peserta KB yang tidak menggunakan
Non Metode Kontrasepsi Jangka Panjang seperti kondom 5,25\%, suntik $52,21 \%$, pil $24,36 \%$, yaitu sebesar $81,83 \%$ dari seluruh peserta $\mathrm{KB}$ baru. Sedangkan peserta KB baru yang menggunakan metode jangka panjang hanya sebesar 18,17\% yang meliputi, Implan 9,73\%, IUD 6,87\%, MOW 1,48\%, MOP 0,10\%Pencapaian peserta KB Baru pada Februari ini secara nasional sebesar 7,79\%. Pencapaian peserta KB baru sampai dengan bulan Februari 2015 sebanyak 1.032.054 peserta. Peserta KB baru yang menggunakan metode jangka panjang sampai dengan bulan Februari 2015 hanya sebesar $17,25 \%$. Jika dibandingkan dengan pencapaian peserta KB baru sampai dengan Februari telah mencapai 15,07\% (BKKBN,2015). Hal ini disebabkan masyarakat Jawa Timur lebih cenderung menggunakan kontraseps lain misalnya suntik, pil, IUD. Di Kabupaten Kediri tahun 2015 dari 312.819 PUS yang memilih menjadi akseptor untuk MOW15.476 akseptor $(28,48 \%)$ (BPPKB kabupaten kediri 2015). Masyarakat Kediri secara umum tingkat sosial ekonominya cukup tinggi sehingga cenderung memilih KB suntik meskipun 1 bulan atau 3 bulan tetap membayar. Data peminat kontrasepsi di Kecamatan Banyakan Kabupaten Kediri dari 11.813 PUS yang memilih menjadi akseptor untuk MOW 475 akseptor $(5,76 \%)$ (BPPKB kabupaten kediri 2015).

$$
\text { Upaya peningkatan }
$$
pengetahuan melalui promosi $\mathrm{KB}$ MOW dengan berbagai media dan penyuluhan yang diharapkan akan meningkatkan pengetahuan masyarakat khususnya bagi pasangan usia subur (PUS), sehingga mereka tau dan mau dengan ikut berpartisipasi menjadi peserta KB MOW. Dukungan Dana 
Alokasi Khusus (DAK) bidang KB yang merupakanbantuan kepada Kabupaten dan Kota tertentu, bertujuan untuk mendanai kebutuhan prasarana dan sarana fisik program $\mathrm{KB}$ guna mendukung Program Kependudukan, Keluarga Berencanadan Pembangunan Keluarga (KKBPK). Salah satu kegiatan prioritas DAK Bidang $\mathrm{KB}$ tahun 2015 yaitu penyediaan sarana dan prasarana pelayanan $\mathrm{KB}$ dengan tujuan mendukung tercapainya sasaran prioritas Rencana Kerja Pemerintah (RKP) tahun 2015 yaitu menurunkan TFR dari 2,6 menjadi 2,37 yang ditandai dengan meningkatnya persentase pemakaian kontrasepsi (CPR) semua cara sebesar $65,2 \%$ (BKKBN, 2015

Dari studi pendahuluan di RT 02 RW 02 Desa Banyakan kecamatan Banyakan kabupaten Kediri dengan metode wawancara dengan wanita PUS, didapatkan data sebagai berikut: dari 10 responden, $10(75 \%)$ wanita PUS belum mengerti dan belum pernah mendapatkan informasi dari tenaga kesehata tentang metode kontrasepsi MOW, sedangkan 3 (25\%) wanita PUS mengerti dan pernah mendapatkan informasi dari teman dan media.

\section{METODE}

Desain penelitian yang digunakan penelitian ini adalah Pra-eksperimental Desain yaitu One Group Pre-Test and Post-Test. Penelitian ini dilakukan dengan cara memberikan Pre-test pengamatan terlebih dahulu sebelum diberikan intervensi, setelah itu diberikan intervensi, dan kemudian dilakukan Post-Test (Notoatmodjo, 2011:57)

Dalam penelitian ini populasinya adalah seluruh wanita Pus di RT 02 RW 02 Desa Banyakan kecamatan
Banyakan kabupaten Kediri sebanyak 33 wanita PUS.

Dalam penelitian ini Sampel yang diambil adalah seluruh wanita Pus di RT 02 RW 02 Desa Banyakan kecamatan Banyakan kabupaten Kediri sebanyak 33 wanita PUS

Dalam penelitian ini, teknik yang digunakan adalah Total Sampling . Variabel independen dalam penelitian ini yaitu penyuluhan tentang metode kontrasepsi MOW.Variabel dependen dalam penelitian ini adalah pengetahuan wanita PUS tentang metode kontrasepsi MOW. 
Erma Herdyana; Perbedaan Pengetahuan Wanita PUS Tentang Metode Kontrasepsi MOW Sebelum dan sesudah Penyuluhan

\section{HASIL}

1. Data Umum:

a. Karakteristik responden berdasarkan umur

Tabel 1 Karakteristik responden berdasarkan umur di RT 02 RW 02 Desa Banyakan Kecamatan Banyakan Kabupaten Kediri.

\begin{tabular}{|c|l|c|c|}
\hline No & Umur (th) & $\begin{array}{c}\text { Jumlah } \\
\text { Responden }\end{array}$ & Presentase (\%) \\
\hline 1. & $21-30$ & 6 & 18,18 \\
2. & $31-40$ & 19 & 57,58 \\
3. & $41-50$ & 8 & 24,24 \\
4. & $>50$ & 0 & 0 \\
\hline & Jumlah & $\mathbf{3 3}$ & $\mathbf{1 0 0}$ \\
\hline
\end{tabular}

b. Karakteristik responden berdasarkan tingkat pendidikan

Tabel 2 Karakteristik responden berdasarkan tingkat Pendidikan di RT 02 RW 02 Desa Banyakan Kecamatan Banyakan Kabupaten Kediri.

\begin{tabular}{|c|l|c|c|}
\hline No & Pendidikan & $\begin{array}{c}\text { Jumlah } \\
\text { Responden }\end{array}$ & Presentase(\%) \\
\hline 1. & SD & 7 & 21,21 \\
2. & SMP & 14 & 42,42 \\
3. & SMA & 12 & 36,37 \\
4. & TDK & 0 & 0 \\
\hline & Jumlah & 33 & 100 \\
\hline
\end{tabular}

A. Karakteristik responden berdasarkan pekerjaan.

Tabel 3 Karakteristik responden berdasarkan Pekerjaan di RT 02 RW 02 Desa Banyakan Kecamatan Banyakan Kabupaten Kediri.

\begin{tabular}{|l|l|c|c|}
\hline No & Pekerjaan & Jumlah Responden & Presentase(\%) \\
\hline 1. & Tidak bekerja & 20 & 60,60 \\
2. & Petani & 7 & 21,21 \\
3. & Wiraswasta & 6 & 18,19 \\
4. & PNS & 0 & 0 \\
\hline & Jumlah & 33 & 100 \\
\hline
\end{tabular}

c. Karakteristik responden berdasarkan pernah tidaknya mendapatkan informasi tentang metode kontrasepsi MOW.

Tabel 4 Karakteristik responden berdasarkan berdasarkan pernah tidaknya mendapatkan informasi di RT 02 RW 02 Desa Banyakan Kecamatan Banyakan Kabupaten Kediri. 


\begin{tabular}{|c|l|c|c|}
\hline No & Pernah/ tidak & $\begin{array}{c}\text { Jumlah } \\
\text { Responden }\end{array}$ & Presentase(\%) \\
\hline 1. & Pernah & 23 & 69,70 \\
2. & Tidak pernah & 10 & 30,30 \\
\hline & Jumlah & 33 & 100 \\
\hline
\end{tabular}

d. Karakteristik responden berdasarkan sumber informasi

Tabel 5 Karakteristik Pengetahuan PUS Metode

Kontrasepsi MOW

Berdasarkan Sumber Informasi di RT 02 RW 02 Desa Banyakan Kecamatan Banyakan Kabupaten Kediri.

\begin{tabular}{clcc} 
No & Pengetahuan & Frekuensi & Presentase $(\%)$ \\
\hline 1. & Penyuluhan & 4 & 17,39 \\
2. & Pelayanan kesehatan & 3 & 13,04 \\
3. & Media Masa & 3 & 13,04 \\
4. & Orang Lain & 13 & 56,52 \\
\hline & Jumlah & 23 & 100
\end{tabular}

a. Pengetahuan wanita PUS tentang metode kontrasepsi MOW sebelum penyuluhan di RT 02 RW 02 Desa Banyakan Kecamatan banyaka Kabupaten Kediri.

Tabel 6 Distribusi pengetahuan PUS tentang metode kontrasepsi MOW sebelum penyuluhan.

\begin{tabular}{clcc} 
No & Pengetahuan & Frekuensi & Presentase $(\%)$ \\
\hline 1. & Baik & 0 & 0 \\
2. & Cukup & 25 & 75,76 \\
3. & Kurang & 8 & 24,24 \\
& & & 100
\end{tabular}

b. Pengetahuan wanita PUS tentang metode kontrasepsi MOW sesudah penyuluhan di RT 02 RW 02 Desa Banyakan Kecamatan banyaka Kabupaten Kediri.

Tabel 7 Distribusi pengetahuan PUS tentang metode kontrasepsi MOW sesudah penyuluhan.

\begin{tabular}{rlcc} 
No & Pengetahuan & Frekuensi & Presentase $(\%)$ \\
\hline 1. & Baik & 28 & 84,84 \\
2. & Cukup & 5 & 15,16 \\
3. & Kurang & 0 & 0 \\
& & & 100
\end{tabular}

c. Tabulasi silang perbedaan pengetahuan PUS tentang metode kontrasepsi MOW sebelum dan sesudah penyuluhan di RT 02 RW 02 Desa Banyakan Kecamatan banyaka Kabupaten Kediri.

Tabel 8 Tabulasi silang perbedaan pengetahuan PUS tentang metode kontrasepsi MOW sebelum dan sesudah penyuluhan di RT 02 RW 02 Desa Banyakan Kecamatan banyaka Kabupaten Kediri

60 | Jurnal Kebidanan Dharma Husada Kediri Vol.6, No.2 April 2017 
Erma Herdyana; Perbedaan Pengetahuan Wanita PUS Tentang Metode Kontrasepsi MOW Sebelum dan sesudah Penyuluhan

\begin{tabular}{|c|c|c|c|c|c|}
\hline \multirow[t]{2}{*}{$\mathrm{NO}$} & \multirow{2}{*}{$\begin{array}{l}\text { Penyuluhan } \\
\text { Kriteria } \\
\text { Pengetahuan }\end{array}$} & \multicolumn{2}{|c|}{$\begin{array}{l}\text { Sebelum } \\
\text { Penyuluhan }\end{array}$} & \multicolumn{2}{|c|}{$\begin{array}{l}\text { Sesudah } \\
\text { Penyuluhan }\end{array}$} \\
\hline & & $\sum$ & $\%$ & $\sum$ & $\%$ \\
\hline 1. & Baik & 0 & 0 & 28 & 84,84 \\
\hline 2 . & Cukup & 25 & 75,76 & 5 & 15,16 \\
\hline 3. & Kurang & 8 & 24,24 & 0 & 0 \\
\hline & Jumlah & 33 & 100 & 33 & 100 \\
\hline
\end{tabular}

Tabel 9 Hasil Uji Wilcoxon Match Pair Test perbedaan

pengetahuan PUS tentang metode kontrasepsi MOW sebelum dan sesudah penyuluhan di RT 02 RW 02 Desa Banyakan Kecamatan banyaka Kabupaten Kediri

\begin{tabular}{|l|r|}
\hline & Sesudah Penyuluhan - Sebelum Penyuluhan \\
\hline Z & $-5.533^{\mathrm{a}}$ \\
Asymp. Sig. (2-tailed) & .000 \\
\hline
\end{tabular}

1. Berdasarkan data dari tabulasi silang sebelum dilakukan penyuluhan didapatkan 33 responden sebagian besar memiliki pengetahuan cukup yaitu 25 responden dengan presentase $(75,76 \%)$ dan 8 responden dengan presentase $(24,24 \%)$ mempunyai pengetahuan kurang.

2. Sedangkan dari data tabulasi silang sesudah dilakukan penyuluhan dari 33 responden, 28 respoden sudah

\section{PEMBAHASAN}

1. Pengetahuan Wanita Pus tentang Metode Kontrasepsi MOW sebelum penyuluhan di Rt 02 Rw 02 Desa Banyakan Kecamatan Banyakan Kabupaten Kediri

Berdasarkan tabel 1 menunjukkan bahwa dari 33 responden didapatkan dengan presentase tertinggi adalah 19 responden $(57,58 \%)$ yang berumur $31-40$ tahun, 8 responden $(24,24 \%)$ yang berumur $41-50$ tahun dan 6 responden $(18,18 \%)$ yang berumur 21-30 tahun.

Usia mempengaruhi daya tangkap dan pola pikir sesorang. Semakin bertambah usia akan semakin berkembang pula daya tangkap mempunyai pengetahuan baik dengan presentase $(84,84 \%)$.

3. Berdasarkan data dari tabulasi silang telah dilakukan uji analisa dan menunjukan menunjukkan hasil $\mathrm{Z}$ sebesar -5.533 dengan tingkat signifikasi $(\sigma)$ sebesar $0.000(\sigma \leq 0,05)$. Karena $\sigma \leq 0,05$, maka $H_{1}$ diterima yang artinya ada Perbedaan Pengetahuan Wanita PUS Tentang Mtode Kontrasepsi MOW Sebelum Dan Sesudah Penyuluhan.

dan pola pikirnya sehingga pengetahuan yang diperolehnya semakin membaik. Usia adalah umur individu yang terhitung mulai saat dilahirkan sampai berulang tahun. Sedangkan menurut Huclok (1998) semakin cukup umur, tingkat kematangan dan kekuatan seseorang akan lebih matang dalam berfikir dan bekerja. Dari segi kepercayaan masyarakat seseorang yang lebih dewasa dipercaya dari orang yang belum tinggi kedewasaannya. Hal ini akan sebagai dari pengalaman dan kematangan jiwa (A.wawan\&Dewi M, 2010:16).

Dari penelitian yang dilakukan bahwa umur wanita berpengaruh terhadap pengetahuan seseorang. Pada dasarnya 
Seseorang yang memiliki umur yang cukup, proses daya tangkap dan pemikirannya akan lebih mudah, serta pengetahuan yang diperoleh dapat diaplikasikan sesuai tujuan yang diharapkan dan pengetahuan yang dimiliki dapat dipahami secara baik dan diharapkan menjadi modal utama dalam mengamplikasikan suatu pengetahuan.

Faktor lain yang mempengaruhi yaitu pendidikan. Berdasarkan tabel 2 menunjukkan bahwa 12 responden $(36,36 \%)$ yang berpendidikan SMA 7 responden $(21,21 \%)$ yang berpendidikan SD dan 4 responden $(42,42 \%)$ yang berpendidkan SMP.

Pendidikan berarti bimbingan yang diberikan seseorang terhadap perkembangar orang lain menuju kearah cita-cita tertentu yang menentukan manusia untuk berbuat dan mengisi kehidupan untuk mencapai keselamatan dan kebahagian. Pendidikan diperlukan untuk mendapat informasi misalnya hal-hal yang menunjang kesehatan sehingga dapat meningkatkan kualitas hidup (A.wawan\&Dewi M, 2010:16).

Tingkat pendidikan mempengaruhi daya tangkap atau penerimaan sesorang terhadap suatu informasi, semakin tinggi pendidikan seseorang semakin banyak pula pengetahuan yang didapatkan, hal tersebut dikarenakan pendidikan sangat penting dalam membentuk perilaku seseorang untuk menjadi dewasa sehingga banyak responden yang dapat menerima informasi dengan mudah. Semakin mudah menerima informasi sehingga semakin banyak pula pengetahuan yang didapatkan.

Selain faktor pendidikan faktor pekerjaan juga mempengaruhi pengetahuan seseorang. Berdasarkan tabel 3 menunjukkan bahwa dari 33 responden terdapat 20 responden $(60,60 \%)$ yang tidak bekerja.

Pengalaman sebagai sumber pengetahuan adalah suatu cara untuk memperoleh kebenaran pengetahuan dengan cara mengulang kembali pengetahuan yang diperoleh dalam memecahkan masalah yang dihadapi masa lalu. Pengalaman belajar dalam bekerja yang dikembangkan akan memberikan pengetahuan dan ketrampilan profesional, serta dapat menegambangkan kemampuan mengambil keputusan yang merupakan manifestasi dari keterpaduan menalar secara imiah dan etik yang bertolak dari masalah nyata dalam bidang kerja (Budiman \& Agus, 2014: 5)

Dari data yang didapatkan bahwa sebagian besar responden tidak memiliki pekerjaan, hal ini dapat menghambat pengetahuan dan ketrampilan sesorang. Sehingga pada saat penyuluhan responden kurang berinteraksi dan kurang terbuka. Meskipun pengetahuan responden tentang metode kontrasepsi MOW baik, tetapi perlu ditekankan lagi bahwa responden harus memperhatikan informasi yang didapatkan.

\section{Pengetahuan Wanita Pus tentang Metode Kontrasepsi MOW sesudah penyuluhan di Rt 02 Rw 02 Desa Banyakan Kecamatan Banyakan Kabupaten Kediri.}

Berdasarkan tabel 7 terdapat 33 responden untuk mengidentifikasi pengetahuan wanita PUS tentang metode kontrasepsi MOW sebelum penyuluhan, dapat diketahui bahwa 28 responden $(84,84 \%)$ dengan pengetehuan baik, 5 responden $(15,16 \%)$ dengan pengetahuan cukup, dan 0 responden $(00,00 \%)$ dengan pengetahuan kurang.

Pengetahuan merupakan hasil "tahu" dan ini terjadi setelah orang mengadakan penginderaan terhadap suatu objek tertentu. Penginderaan terhadap obyek terjadi melalui panca indera manusia yakni penglihatan, pendengaran, penciuman, rasa dan raba dengan sendiri. Pada waktu penginderaan sampai menghasilkan pengetahuan tersebut sangat dipengaruhi oleh intensitas perhatian persepsi terhadap obyek. (A.wawan\&Dewi M, 2010:11).

Dari hasil penelitian yang dilakukan pengetahuan wanita PUS tentang metode kontrasepsi MOW menjadi baik. Hal ini dapat dilihat dari data tabulasi persub bab berdasarkan kisi-kisi menunjukkan bahwa yang sebelum penyuluhan masih terdapat kriteria kurang dan setelah dilakukan penyuluhan kriteria responden baik tidak ada kriteria yang kurang. 
Selain faktor diatas, faktor umur juga dapat berpengaruh terhadap pengetahuan seseorang, berdasarkan tabel tabel IV.I yaitu karakteristik responden yang dipengaruhi oleh umur. Didapatkan hasil bahwa 19 responden $(57,58 \%)$ berumur $31-40$ tahun, 8 responden $(24,24 \%)$ berumur $41-50$ tahun dan 6 responden $(18,18 \%)$ berumur $21-30$ tahun.

Usia mempengaruhi daya tangkap dan pola pikir sesorang. Semakin bertambah usia akan semakin berkembang pula daya tangkap dan pola pikirnya sehingga pengetahuan yang diperolehnya semakin membaik. Usia adalah umur individu yang terhitung mulai saat dilahirkan sampai berulang tahun. Sedangkan menurut Huclok (1998) semakin cukup umur, tingkat kematangan dan kekuatan seseorang akan lebih matang dalam berfikir dan bekerja. Dari segi kepercayaan masyarakat seseorang yang lebih dewasa dipercaya dari orang yang belum tinggi kedewasaannya. Hal ini akan sebagai dari pengalaman dan kematangan jiwa (A.wawan\&Dewi M, 2010:16).

\section{Perbedaan Pengetahuan Wanita PUS tentang Metode Kontrasepsi MOW Sebelum dan Sesudah Penyuluhan di Rt 02 Rw 02 Desa Banyakan Kecamatan Banyakan Kabupaten Kediri.}

Berdasarkan tabel 8 hasil dari 33 responden terdapat perbedaan yang cukup signifikan yaitu pada pengetahuan wanita PUS sebelum diberikan penyuluhan tentang metode kontrasepsi MOW terdapat 0 responden $(0.00 \%)$ yang mempunyai pengetahuan baik, 25 responden $(75,76 \%)$ yang mempunyai pengetahaun cukup dan 8 responden $(24,24 \%)$ yang mempunyai pengetahuan kurang. Setelah dilakukan penyuluhan tentang metode kontrasepsi MOW didapatkan 28 responden $(84,84 \%)$ yang mempunyai pengetahuan baik, 5 responden $(15,16 \%)$ yang mempunyai pengetahuan cukup, dan 0 responden $(0,00 \%)$ yang mempunyai pengetahuan kurang.

Informasi dapat didefinisikan sebagai suatu teknik untuk mengumpulkan, menyimpan, memanipulasi, mengumumkan, menganalisis, dan menyebarkan informasi dengan tujuan tertentu. Adanya informasi baru mengenai sesuatu hal yan diberikan landasan kognitif baru bagi terbentuknya pengetahuan tersebut (Budiman \& Agus, 2014: 5).

Pengetahuan responden mengenai metode kontrasepsi MOW mempunyai nilai yang cukup berbeda-beda. Hal ini karena dipengaruhi oleh banyak faktor. Dapat dilihat ada perbedaan yang mencolok antara pengetahuan wanita PUS tentang metode kontrasepsi MOW sebelum dan sesudah penyuluhan. Oleh karean itu penyuluhan tersebut sangat berpengaruh terhadap pengetahuan wanita PUS tentang metode kontrasepsi MOW.

Selain faktor diatas, faktor umur juga dapat berpengaruh terhadap pngetahuan seseorang, berdasarkan tabel tabel I yaitu karakteristik responden yang dipengaruhi oleh umur. Didapatkan hasil bahwa 19 responden $(57,58 \%)$ berumur $31-40$ tahun, 8 responden $(24,24 \%)$ berumur $41-50$ tahun dan 6 responden $(18,18 \%)$ berumur 21-30 tahun.

Usia mempengaruhi daya tangkap dan pola pikir sesorang. Semakin bertambah usia akan semakin berkembang pula daya tangkap dan pola pikirnya sehingga pengetahuan yang diperolehnya semakin membaik. usia adalah umur individu yang terhitung mulai saat dilahirkan sampai berulang tahun. Sedangkan menurut Huclok (1998) semakin cukup umur, tingkat kematangan dan kekuatan seseorang akan lebih matang dalam berfikir dan bekerja. Dari segi kepercayaan masyarakat seseorang yang lebih dewasa dipercaya dari orang yang belum tinggi kedewasaannya. Hal ini akan sebagai dari pengalaman dan kematangan jiwa (A.wawan\&Dewi M, 2010:16).

Dari data diatas menjelaskan bahwa prosentase tertinggi 19 responden $(57,58 \%)$ berumur 31-40 tahun. Semakin usia sesorang bertambah, semakin dewasa pola fikir seseorang. Proses pendewasan mempengaruhi daya tangkap seseorang untuk semakin berkembang. Hal ini yang mempengaruhi seseorang dalam menerima 
informasi dan diamplikasikan sesuai tujuan yang diharapkan.

Faktor lain yang juga berpengaru terhadapa pengetahuan yaitu pendidikan. Hasil penelitian ditunjukkan pada tabel 2 menunjukkan bahwa 12 responden $(36,36 \%)$ yang berpendidikan SMA, 4 responden $(42,42 \%)$ yang berpendidkan SMP dan 7 responden $(21,21 \%)$ yang berpendidikan SD.

Pendidikan berarti bimbingan yang diberikan seseorang terhadap perkembangan orang lain menuju kearah cita-cita tertentu yang menentukan manusia untuk berbuat dan mengisi kehidupan untuk mencapai keselamatan dan kebahagian (A.wawan\&Dewi M, 2010:16).

Tingkat pendidikan mempengaruhi daya tangkap atau penerimaan seseorang terhadap suatu informasi. Semakin tinggi pendidikan seseorang semakin mudah penerimaannya, tetapi buakan berarti seorang yang mempunyai pendidikan rendah susah menerima informasi, karena pengetahuan atau informasi tidak hanya didaptkan dari pendidikan dari media lain juga bisa.

Selain faktor umur dan pendidikan faktor pekerjaan juga dapat mempengaruhi pengetahuan seseorang. Berdasarkan tabel 3 menunjukkan bahwa dari 33 responden terdapat 20 responden $(60,60 \%)$ yang tidak bekerja.

Pengalaman sebagai sumber pengetahuan adalah suatu cara untuk memperoleh kebenaran pengetahuan dengan cara

\section{DAFTAR PUSTAKA}

A. Wawan \& Dewi M.,2010.Teori dan pengukuran pengetahuan, sikap,dan perilaku:manusia. Yogyakarta: Nuha Medika

S. Arum \& Sujiatin.,2011. Panduan lengkap pelayanan $K B$ terkini.Jogjakarta: PustakaNuha Medika mengulang kembalipengetahuan yang diperoleh dalam memecahkan masalah yang dihadapi masa lalu. Pengalaman belajar dalam beekerja yang dikembangkan akan memberikan pengetahuan dan ketrampilan profesional, serta dapat mengembangkan kemampuan mengamil keputusan yang merupakan manifestasi dari keterpauan menalar secara ilmiah dan etika yang bertolak dari masalah nyata dalam bidang kerjanya ( Budiman \& Agus, 2014: 5)

\section{KESIMPULAN}

1. Pengetahuan wanita PUS sebelum diberi penyuluhan tentang metode kontrasepsi MOW sebanyak 25 responden $(75,76 \%)$ dengan pengetahuan cukup.

2. Pengetahuan wanita PUS sesudah diberi penyuluhan tentang metode kontrasepsi MOW sebnyak 28 responden $(84,84 \%)$ dengan pengetahuan baik.

3. Diadapatkan hasil $H_{1}$ diterima yang artinya adanya perbedaan pengetahuan wanita PUS sebelum dan sesudah penyuluhan hal tersebut setelah dilakukan uji statistik dengan menggunakan Wilcoxon Matc Pair Test menunjukkan hasil $\mathrm{Z}$ sebesar -5.533 dengan tingkat signifikasi $(\sigma)$ sebesar $0.000(\sigma \leq 0,05)$. Karena $\sigma \leq 0,05$.

Budiman, agus riyanto. 2014. Pengetahuan dan sikap dalam penelitian kesehatan.jakarta: salemba medika

Mulyani \& Rinawati. 2013. $K B$ keluarga berencana dan alatkontrasepsi. Yogyakarta:Nuha Medika

Romauli \& Vindari. 2012. Kesehatan reproduksi buat mahasiswa 
Erma Herdyana; Perbedaan Pengetahuan Wanita PUS Tentang Metode Kontrasepsi MOW Sebelum dan sesudah Penyuluhan

kebidanan. Yogyakarta: Nuha Medika

Hidayat, Alimul.2014. Metode Penelitian Kebidanan Dan Analisis Data. Jakarta: Salemba Medika

Manuaba, I. Ayu,Bagus \& Gde. 2010. Ilmu kebidanan, penyakit kandungan, dan $\quad K B$ umtukpendidikan bidan. Jakarta: EGC

Nasir, A. Muhith, A. \& Ideputri M. 2011. Metode penelitian kesehatan. Yogyakarta: Nuha Medika

Nursalam. 2013. Konsep Dan Penerapan Metodelogi Penelitian Ilmu keperawatan. Jakarta: Salemba Medika

Proverawati, A. Islaely, A. \& Aspuah S. 2010. panduan memilih kontrasepsi. Yogyakarta:Nuha Medika

Mubarak, W. 2011. Promosi kesehatan untuk kebidanan. Jakarta: Saleba Medika

Saifuddin, A. Affandi, B. Baharuddin, M. \& Soekir S. 2011. Buku panduan praktis pelayanan kontrasepsi. Jakarta: Yayasan Bina Pustaka Sarwono Prawirohardjo

Sugiono. 2011. Statistik Untuk Penelitian. Jakarta: EGC

Notoatmodjo. 2010. Metode penelitian Kesehatan. Jakarta: Rineka Cipta
Seto, D. H. Saryono, \& Iswati, N. 2011. Jurnal Ilmu Kesehatan Keperawatan [online] vol 7, hal.71-2. jtstikesmuhgo-gdldhinihariy-1329-2-

BKKBN, 2015. SE No. 212/PER/B1/2015 Rencana Strategis Badan Kependudukan Dan Keluarga Berencana Nasional Tahun 2015 -

2019. Jakarta : Biro Perencanaan $\mathrm{BKKBN}$

BKKBN, 2014. Laporan Umpan Balik

Hasil Pelaksanaan Sub sistem

Pencatatan Dan

Pelaporan.[Online] (Updated

Januari 2015) Diakses dari:

http://.Laporan \%20Hasil\%20Pelaya

nan\%20Kontrasepsi\%20Januari\%2

02014[19 April 2016]

BKKBN, 2015. Laporan Umpan Balik

Hasil Pelaksanaan Sub

sistemPencatatan Dan

Pelaporan.[Online] (Updated

februari 2015) Diakses dari:

http://.Laporan\%20Hasil\%20Pelaya nan\%20Kontrasepsi\%20FEBRUAR I\%202015[26 April 2016]

BPPKB Kabupaten kediri, 2015. Data

Peserta Kb Aktif Menurut Tempat

Pelayanan[Online] (Updated 2015)

Diakses dari

:https://kedirikab.go.id/data/data-

kesehatan/1950-keluarga-berencana-

kb.html[13 Mei 2016] 